\title{
РЕЦЕНЗИИ
}

\section{Debates on the Peasant Question in the Nikolaevan Era}

\section{A.M.Martin}

For citation: Martin A. M. Debates on the Peasant Question in the Nikolaevan Era. Vestnik of Saint Petersburg University. History, 2021, vol. 66, issue 1, pp. 293-301.

https://doi.org/10.21638/11701/spbu02.2021.118

A large scholarly literature exists about plans for a peasant reform in the reign of Nicholas I. However, the most important archival documents about the debates on the peasant question remain unpublished. The new book by T. V. Andreeva "The distant approaches to the Great Reform: The peasant question in Russia in the reign of Nicholas I" seeks to fill this lacuna. The book begins with a historical survey of the six government committees that were tasked with planning reforms, followed by an extensive collection of archival documents of both official and private provenance. In the debates under Nicholas I, the specific problem of serfdom was folded into the larger question of the social position of the peasants, which the government regarded as a source of both political instability and economic backwardness. The solution that officials envisioned was a reform that was comprehensive, multi-faceted, and gradual. Step-by-step, the evolution that had led to creation of serfdom from the $17^{\text {th }}$ century onward was to be reversed: the landlords were gradually to lose their power over the person of the serfs, who were to be attached only to the land itself. Eventually, the serfs were to be emancipated with land; in the meantime, restrictions on the power of landlords and a comprehensive reform of the state peasants were to serve as preparatory steps. According to Andreeva, the vision of Nicholas and his advisors was too limited and conservative, and premised on the mistaken belief that it was possible to modernize the country without touching the core of the sociopolitical system.

Keywords: serfdom, state peasants, peasant question, secret committees, Nicholas I, Great Reforms, P.D. Kiselev.

Alexander Michael Martin - PhD, Professor, University of Notre Dame, 434, Decio Hall, Notre Dame, Indiana, 46556, USA; a.m.martin@nd.edu

Александр М. Мартин - PhD, проф., Университет Нотр Дам, США, Индиана, 46556, Нотр Дам, Десио Холл, 434; a.m.martin@nd.edu

(C) St. Petersburg State University, 2021 


\section{Споры о крестьянском вопросе в Николаевскую эпоху}

A. М. Мартин

Для цитирования: Martin A. M. Debates on the Peasant Question in the Nikolaevan Era // Bестник Санкт-Петербургского университета. История. 2021. Т.66. Вып. 1. С. 293-301. https://doi.org/10.21638/11701/spbu02.2021.118

Существует объемная историография о планах крестьянской реформы в царствование Николая I. Однако важнейшие архивные документы о дебатах по крестьянскому вопросу остаются неопубликованными. Новая книга Т. В. Андреевой «На дальних подступах к Великой реформе: крестьянский вопрос в России в царствование Николая I» стремится восполнить эту лакуну. Книга начинается с исторического обзора шести правительственных комитетов, которым было поручено планировать реформы, после чего следует обширная коллекция архивных документов как официального, так и частного происхождения. В дебатах при Николае I специфическая проблема крепостничества складывалась в более масштабный вопрос о социальном положении крестьян, который правительство рассматривало как источник политической нестабильности и экономической отсталости. Чиновники видели решение во всеобъемлющей, многогранной и постепенной реформе. Шаг за шагом эволюция, приведшая к созданию крепостного права с XVII в. и далее, поворачивалась вспять: помещики постепенно теряли свою власть над личностью крепостных, которые должны были быть привязаны только к самой земле. В конце концов крепостных крестьян следовало освобождать с землей, а подготовительными шагами являлись ограничения власти помещиков и всеобъемлющая реформа государственных крестьян. По мнению Андреевой, видение Николая и его советников - слишком ограниченное и консервативное - основывалось на ошибочном убеждении, что модернизировать страну можно, не касаясь ядра социально-политической системы.

Ключевые слова: крепостное право, государственные крестьяне, крестьянский вопрос, тайные комитеты, Николай I, Великие реформы, П. Д. Киселев.

Historical scholarship has increasingly made clear that the abolition of serfdom had origins extending far back into the reign of Nicholas I and even Alexander I. In the book under review, T. V. Andreeva examines the work of six secret committees that studied the peasant question under Nicholas I, and shows how their discussions laid the foundation both for the reform of the state peasants in the 1840s and the subsequent abolition of serfdom ${ }^{1}$. This analysis is followed by the publication, for the first time, of a significant number of archival sources from the 1820-1840s that document the diversity of opinions that existed about the peasant question in the reign of Nicholas I.

From the late $18^{\text {th }}$ to the mid- $19^{\text {th }}$ century, the "peasant question" played an important, often tragic role in the history of many countries. The French peasants overthrew their lords in 1789 and fought against the republic in the Vendée. Peasant poverty made southern Italy and Sicily into lands of economic stagnation and brigandage. The Irish peasants died of hunger by the hundreds of thousands in the 1840s. In the USA in 1861, the conflict over slavery triggered a civil war. By these standards, the abolition of serfdom

${ }^{1}$ Andreeva T. Na dal'nykh podstupakh k Velikoi reforme: Krest'ianskii vopros v Rossii v tsarstvovanie Nikolaia I. St. Petersburg, 2019. 
in Russia was unusually successful, inasmuch as it protected the interests of the peasants and also avoided throwing the state into chaos. The prehistory of this success - how the emancipation was prepared in the reign of Nicholas I - is the subject of the new book by T.V.Andreeva. Drawing on massive archival research into the debates about the peasant question in the upper echelons of Nicholas I's government, the book is made up of two unequal parts: the first 20 percent is a review of the historiography followed by a history of the governmental committees that discussed the peasant question from the 1820s to the 1840s; the remaining 80 percent is a collection of previously unpublished archival documents.

The book opens with an extensive analysis of the historiography. The broad theme is how scholars stopped seeing the 1850s as a sharp break between an age of reaction and one of reform, and instead came to interpret the entire period from the 1790s onward as characterized by a continuous effort to promote modernizing reforms of a bourgeois type. The key figure is N. M. Druzhinin, who, in the 1940s, developed two ideas that have become central to modern interpretations of the peasant question: that there was a longterm continuity of reform initiatives from the reign of Nicholas I to that of Alexander II, and that the reforms of the state peasants by P.D. Kiselev formed a precursor to the later abolition of serfdom ${ }^{2}$. Druzhinin's ideas received extensive further development in the late Soviet period by S. V.Mironenko, but above all by P. A. Zaionchkovskii ${ }^{3}$; the latter served as a mentor to a whole generation of British and American historians, and through them, the idea that Nicholas's reign was an era of cautious reform became accepted in Western scholarship as well ${ }^{4}$.

In the post-Soviet period, this has become a mainstream thesis. Andreeva is critical of the position of B. N. Mironov that the serfdom of the peasants was similar in fundamental ways to the authoritarian structures under which other estates lived, and that serfdom was a viable socioeconomic system and was abolished primarily for ideological reasons ${ }^{5}$. Instead, she argues that the monarchs from Alexander I onward worked toward its abolition because they rightly saw it as a dysfunctional system that would eventually undermine Russia's status as a great power; in this, she writes, she concurs with A.N. Tsamutali, V. G. Chernukha, I. K. Pantin, E. G. Plimak, L. V. Vyskochkov, I. A. Khristoforov and I. V. Ruzhitskaia. She adds that her own opinion of the reform plans of the Nikolaevan era is quite critical: they were, in her view, too strongly influenced by Western models that were incompatible with the structures of Russian society, and they did not go far enough in trying to modernize the country for they aimed only to introduce a modicum of capitalist development while leaving the feudal foundations of the social system intact.

\footnotetext{
${ }^{2}$ Druzhinin N. Gosudarstvennye krest'iane i reforma P. D. Kiseleva: v 2 t. Moscow; Leningrad, 19461958.

${ }^{3}$ Mironenko S. Samoderzhavie i reformy: Politicheskaia bor'ba v Rossii v nachale XIX v. Moscow, 1989. P. 61-146; Zaionchkovskii P. Pravitel'stvennyi apparat samoderzhavnoi Rossii v XIX v. Moscow, 1978. P. 106-113.

4 Pintner W. Russian economic policy under Nicholas I. Ithaca, 1967; Wortman R. The development of a Russian legal consciousness. Chicago, 1976; Lincoln W. In the vanguard of reform: Russia's enlightened bureaucrats, 1825-1861. DeKalb, 1986; McCaffray S. Confronting serfdom in the Age of Revolution: Projects for serf reform in the time of Alexander I // The Russian Review. 2005. Vol. 64, issue 1. P. 1-21.

${ }^{5}$ Mironov B. Sotsial'naia istoriia Rossii perioda imperii (XVIII - nachalo XX v.): Genezis lichnosti, demokraticheskoi sem'i, grazhdanskogo obshchestva i pravovogo gosudarstva: v 2 t. Vol. 1. St. Petersburg, 1999. P. 408, 414.
} 
In concluding her survey of the historiography, Andreeva finds that "the main aspects of the peasant question in the second quarter of the $19^{\text {th }}$ century have been studied in the scholarly literature", but the problem nonetheless "has not been fully researched" because major documents concerning debates about the peasant question, of both official and private provenance, remain unpublished. The present book is intended to "fill this lacuna" (p. 45).

The next section of the book is a history of the six secret committees under Nicholas I that attempted to grapple with the peasant question between 1826 and 1842. One important theme of this history is continuity. The successive committees included many of the same people. Some had already been prominent statesmen under Alexander I, such as M. M. Speranskii, V.P. Kochubei, A. N. Golitsyn, or N.S. Mordvinov; others were senior figures of Nicholas I's entourage, such as P.D. Kiselev and E. F. Kankrin. The starting point for the committees' work was the last major attempt at a peasant reform, Alexander I's Edict on Free Agriculturalists of 1803. From one committee to the next, discussions of the same ideas were carried forward. The various Nikolaevan committees were in effect only changing incarnations of a single conversation about the peasant question, and more generally - about state and society in the Russian Empire, which had its origin in the early years of Alexander I's reign.

The other important theme is the complexity of the peasant question. The problem was of course complex in its essence since it touched the lives of most of the empire's population, but the Russian government also chose to make it complex. It conceived the problem to be not serfdom as such - that is, the power of the nobles to make arbitrary decisions about the individual person of the peasants - but a more broadly defined "peasant question" that included the entire web of relationships connecting both serfs and state peasants to every aspect of the sociopolitical system. Correspondingly, the concerns of Nicholas I and his entourage were multifaceted: they included a desire to modernize the economy and maximize tax revenues, fear of peasant rebellions, concerns about Russia's international prestige, and a sense that for one human being to own another was morally wrong. Likewise, the political calculations were complicated because the secret committees wanted to balance the interests of the nobles, the peasants, and the state, and prevent a hostile reaction to the proposed reforms from either the nobles or the peasants. Lastly, because the committees were tasked with proposing actual legislation, they had to confront the many difficult practical questions that a comprehensive reform of the peasantry would raise.

As Andreeva shows, the great accomplishment of the secret committees was to clarify these complexities and build consensus around certain principles. The power of the landlords over the person of the peasants was to be abolished, but in other ways, the proposed reform was not really an emancipation, but rather a limited reorganization of the estate-based autocratic system; freedom and humanitarian progress would be by-products, not the reform's central thrust.

Several principles emerged from the committees' discussions. First, the dismantling of serfdom should occur slowly, almost imperceptibly, over decades. There should be no sudden, dramatic emancipation. Instead, reforms of individual aspects of serfdom should be embedded in larger legislative acts that offered benefits not only to peasants but also to other estates. Over time, the accumulation of partial reforms would dismantle serfdom as an overall system, but without destabilizing either the autocracy or the hierarchy of estates. 
Second, the abolition of serfdom would be preceded by a reorganization of the state peasants. This reform of the state peasants would create an improved system of agriculture and rural administration; forward-looking landlords, so it was hoped, would see the advantages of this model and implement it voluntarily for the serfs on their estates, and later the more conservative nobles would have to be compelled to do the same. The reform of the state peasants would thus lead quasi-naturally to a reform of serfdom, with the government having to exercise only a minimum of coercion.

Third, the committees did not base their reflections - as Russian reformers often did in the $18^{\text {th }}$ century, or as the American anti-slavery movement did - on abstract, universal philosophical principles. Instead, they took a typically $19^{\text {th }}$ century historicist and ethnographic approach and decided that serfdom had to be understood in its specifically Russian context. Their aim was not, as it was for the American abolitionists, to build a new society for the future, but to strengthen the estate-based autocratic regime that they thought was the natural outcome of Russia's historic development. Serfdom, they believed, was an aberration that had come into being through a particular process, and if this process were reversed, Russia could arrive at a sociopolitical order that in fact expressed the country's true historic essence. In the $16^{\text {th }}$ century, the nobles had only been landowners who contracted with peasants to farm their land. Over time, they had gained power over the persons of the peasants, including the right to inflict corporal punishments, turn them into landless house serfs, sell them as individuals, and use them as collateral for bank loans. Abolishing serfdom meant reversing this process: ending the sale of individual peasants and their transformation into house serfs; legally regulating their land allotments and obligations to the nobles; making land, not "souls," the basis for taxation and bank loans; and ending the nobles' right to inflict punishments. The outcome would be that the nobles would remain in possession of the land, and the peasants would be legally attached to the land but not to the person of its owner.

In certain areas, no consensus was reached, but the fact that they were discussed reveals something about the preoccupations of Russian officials. Prominent among these was the question of communal land management. Nicholas I was determined that serfs should only be emancipated with land; he thought the landless emancipation in the Baltic Provinces had led to the peasants' pauperization, that mass poverty had caused the 1830 revolutions in France and Belgium, and that P. D. Kiselev's land reform in the Danubian Principalities had been a success that Russia should emulate. But how the peasants' land should be managed was open to debate. There was agreement that the practice of redistributing land led to economic backwardness, but it also prevented the emergence of a class of pauperized landless peasants, and it was not clear that the peasants were culturally prepared for a transition to a more modern and efficient system in which each family had its own hereditary farm.

All of these discussions were carried on in an atmosphere of both urgency and nonchalance. There was urgency because the regime feared that the peasants might rebel if nothing was done, but it also worried that they might rebel if their hopes were raised unrealistically by rumors that reforms were in the works; for that reason, the committees worked in great secrecy. The revolutions of 1830 in Western Europe created additional pressure to take action before it was too late. On the other hand, there was also a confidence - remarkable, from a post- 1855 perspective - that reforms could be implemented over a period of decades, and that the underlying feudal and autocratic system could 
remain intact. The expectation was that, so long as the necessary steps were initiated in a timely way, the Russian Empire had many years' time to carry out the reform of the peasantry. The crisis triggered by the Crimean War was not anticipated.

It is instructive, although Andreeva does not do so, to compare these discussions with those in the United States at the same time about slavery. The comparison makes it easier to see the distinctive conditions that shaped the reform debate in Russia, and why it seemed possible to abolish serfdom without threatening the survival of the social system as a whole. The labor system in Russia was more capitalist than in America: Russian serfowners were often absentees who collected obrok or had a steward oversee barshchi$n a$, but did not directly manage their serfs' labor or control their personal lives as their American counterparts did. The economic activities of Russian nobles, on the other hand, were less capitalist than those in America because they could borrow money on favorable terms from the state and were not wholly dependent on the production of commercial commodities. Russian nobles were vastly outnumbered by the peasantry, whereas whites in the American South outnumbered slaves, so serf revolts were a far more real possibility than were slave revolts in America. Russian nobles operated in a European environment where most countries had monarchical and estate-based regimes but had abolished serfdom, so one could question serfdom without attacking the legitimacy of the regime; in America, by contrast, slavery was the centerpiece of the bitter antagonism between the liberal capitalist ideology of the North and the quasi-feudal ideology of the South. Lastly, the Russian serfowners had little organized political power, unlike American slaveowners. In sum, the American slaveowners formed a powerful, economically strong, ideologically unified bloc, and abolishing slavery meant destroying an entire social system. Russian serfowners, by comparison, were politically and economically weak and lacked a strong sense of ideological purpose; abolishing serfdom promised to invigorate the economy and reduce the danger of rebellion, and could be done without attacking the underlying semi-feudal, semi-capitalist system of socioeconomic relations on which the power of the nobility rested ${ }^{6}$.

Andreeva arrives at a mixed verdict about the reform efforts under Nicholas I. A multitude of laws were passed that addressed individual facets of serfdom, such as laws banning the sale of serfs as individuals or without land: "The fundamental tendency - binding the serfs to the land instead of a master, as a first step toward emancipation - was achieved by taking a multifaceted approach and dividing the overall problem of serfdom into distinct tasks that could be solved by gradually restricting the landlords' powers" (p. 132). These reform efforts laid the conceptual and ideological foundations for the eventual reform. Ultimately, though, the vision of Nicholas and his advisors was too limited and conservative, and premised on the mistaken belief that it was possible to modernize the country without touching the core of the sociopolitical system. The tragic outcome was that "the regime's powers for effecting change dwindled, and the time in which Russia could have carried out fundamental reforms was wasted" (p. 133).

After thus concluding her historical analysis, Andreeva devotes the remainder of the book to reproducing previously unpublished archival documents from those debates. There are 28 documents, each reproduced in full and extensively annotated, taking up over 550 pages of text. Most are by senior state officials such as N. N. Murav'ev, A. B. Kurakin,

${ }^{6}$ Field D. The end of serfdom: Nobility and bureaucracy in Russia, 1855-1861. Cambridge, 1976. P. 38-40; Kolchin P. Unfree labor: American slavery and Russian serfdom. Cambridge, 1987. P.360-362. 
E. F. Kankrin, P.D. Kiselev, and M. M. Speranskii; a few are by more obscure figures. For anyone interested in Russian political thinking in the second quarter of the $19^{\text {th }}$ century, these documents make for fascinating reading.

The documents vividly demonstrate how much had changed in the thinking of the Russian elite since the $18^{\text {th }}$ century. The authors almost never reason from abstract principles. Compared with, say, Catherine II's Nakaz, it is striking how untheoretical their arguments are. Moral, philosophical, and religious ideas no doubt influenced the atmosphere in which the discussions were conducted, but they are not presented explicitly. Other than a brief observation, in a document by K. P. Repinskii, that selling people at auction is "contrary to the moral sense" (p. 299), it is hard to find articulations of universal principles.

The arguments about the past and present of serfdom are historicist, and except for E. F. Kankrin, who in 1827 places the history of Russian serfdom in a European context (p. 585-586), the history in which the arguments are grounded is specifically Russian. Conservatives defend serfdom as a source of Russian greatness: D. O. Baranov writes in 1826 that Catherine II first had to free herself from the influence of "the writers of the first half of the $18^{\text {th }}$ century, who knew nothing about Russia"; only then did she realize that "the root of Russia's might and well-being is the autocracy of the SOVEREIGN, which is founded on the landlords' power over the serfs" (p. 531-532). Reformers, on the other hand, treated serfdom as a deviation from the true Russian tradition. Both the instruction to a committee in 1839 tasked with finding a way to end serfdom, and P. D. Kiselev in 1840, argue that the nobles historically and rightfully owned the land, but that the personal enserfment of the peasants was an aberration and should be undone (p. 317, 346).

When they look to the future, the authors' arguments are influenced by the diversity of models presented by contemporary Europe. There is broad agreement that the goal of a peasant reform is to increase economic productivity and maintain the estate-based autocratic system, but how to achieve this? Are individual farms superior to communal landholding? Yes, says the 1828 committee headed by A. B. Kurakin: the experience of agriculture "in the civilized [obrazovannykh] regions of Europe and within the boundaries of our Baltic provinces" shows the superiority of private farming (p. 185). No, says N. N. Murav'ev in 1826: "In Russia, every agriculturalist is also the owner of a house, and rents, so to speak, a portion of the field, meadow, and forest, so he is no hired worker such as we see in Prussia, Germany, Italy, France, Spain, England, etc." (p. 159). Was urbanization and industry the way of the future? Yes, says N.S. Mordvinov in 1825: "Russia has fallen behind other nations in enriching herself, because she has so far preferred agricultural activities over urban industry" (p. 472). No, says a document from 1847-1849 by deputies of the Smolensk nobility: if peasants become urban workers, Russia will experience the same as "we see now in the states of Europe, where free labor has promoted the growth of industry and given rise to the liberal ideas of communism. Now the states are crumbling, and their flourishing industry is not saving them from ruin" (p. 456).

While the authors insist on Russia's uniqueness, their discussion of its natural and human resources has a pessimistic undertone. The noble deputies from Smolensk argue that Russia, unlike Europe, has a labor shortage and a climate that is bad for agriculture; these differences cause Europe and Russia to have "two distinct systems of civilization", which is why Russia cannot follow Europe in abolishing serfdom (p. 451). Attitudes about Russia's human resources are likewise pessimistic. A.N.Bakhmetev and E. Nedobrovo denounce the corruption and oppressiveness of the officials who govern the state peas- 
ants (p. 168-169, 525-526). Nor do the authors harbor illusions about the peasants. The documents depict the peasants as ignorant, irrational, and incapable of understanding abstract legal concepts. For critics of serfdom such as A. B. Kurakin, this meant that any reform had to be planned and carried out slowly and in total secrecy, to avoid creating a dangerous confusion in the peasants' "narrow and simple ideas" (p. 230). For defenders of serfdom, it meant that emancipation was inherently a foolish idea. D. O. Baranov argues in 1828 that the typical peasant "has no other idea of freedom except that he will not work for the landlord or have to pay dues, and that he can be a vagabond as much as he wishes" (p. 532). Fortunately, he added, "enlightenment" had not yet reached the common man, so he continued to accept that "his lot is unquestioning obedience to the established authorities" (p. 533). Or, as he put it a few pages later: under a well-run autocracy, "the common people pay taxes, provide conscripts, and obey" (p. 537).

That negative claims like these were made about Russia's natural environment, its bureaucracy, and its peasants, will not surprise anyone familiar with $19^{\text {th }}$ century Russian thought. It is interesting, though, that they were not answered by positive counter-claims. Arguments could have been made about the fertile steppe lands available for settlement, about the improvement that rising education levels were effecting in the bureaucracy, or about the natural intelligence, kindness, and talent of the Russian peasant. An optimistic picture of Russia's possibilities would fit the impression one gains from much of the newer scholarship, at least by historians in the West, which tends to argue that the criticisms of pre-Reform Russian society - the claims about its corrupt civil servants, ignorant merchants, backward commercial relations, arbitrary law courts, nobles estranged from the Russian language and culture, and rigid, oppressive estate system, and so on - are exaggerated $^{7}$. If the documents published by T. V. Andreeva are at all representative, however, such favorable assessments, as well as the Nikolaevan regime's own propaganda about Russia’s civilizational accomplishments and great future potential, were not widely believed inside the regime itself.

\section{References}

Andreeva T. The distant approaches to the Great Reform: The peasant question in Russia in the reign of Nicholas I. St. Petersburg, Istoricheskaia illiustratsiia Publ., 2019, 728 p. (In Russian)

Antonov S. Bankrupts and usurers of imperial Russia: Debt, property, and the law in the age of Dostoevsky and Tolstoy. Cambridge, Harvard University Press, 2016, 387 p.

Antonova K. An ordinary marriage: The world of a gentry family in provincial Russia. New York, Oxford University Press, 2013, 304 p.

Druzhinin N. The state peasants and the reform of P. D. Kiseslev. Moscow; Leningrad, Izd-vo Akademii Nauk SSSR, 1946-1958. Vol. 1, 631 p.; Vol.2, 617 p. (In Russian)

Field D. The end of serfdom: Nobility and bureaucracy in Russia, 1855-1861. Cambridge, Harvard University Press, 1976, $472 \mathrm{p}$.

7 See, for example: Schattenberg S. Die korrupte Provinz? Russische Beamte im 19. Jahrhundert. Frankfurt, 2008. P. 83; Ransel D. A Russian merchant's tale: The life and adventures of Ivan Alekseevich Tolchënov, based on his diary. Bloomington, 2009. P.XXIV-XXV; Smith A. For the common good and their own well-being: Social estates in imperial Russia. New York, 2014. P. 13; Antonov S. Bankrupts and usurers of imperial Russia: Debt, property, and the law in the age of Dostoevsky and Tolstoy. Cambridge, 2016. P.3; Offord D., Rjéoutski V., Argent G. The French language in Russia: A social, political, cultural, and literary history. Amsterdam, 2018. P.35-44; Antonova K. An ordinary marriage: The world of a gentry family in provincial Russia. New York, 2013. P. 233. 
Kolchin P. Unfree labor: American slavery and Russian serfdom. Cambridge, The Belknap Press of Harvard University Press, 1987, $517 \mathrm{p}$.

Lincoln W. In the vanguard of reform: Russia's enlightened bureaucrats, 1825-1861. DeKalb, Northern Illinois University Press, 1986, 297 p.

McCaffray S. Confronting serfdom in the Age of Revolution: Projects for serf reform in the time of Alexander I. The Russian Review, 2005, vol.64, iss. 1, pp. 1-21.

Mironenko S. The autocracy and reforms: The political struggle in Russia at the beginning of the $19^{\text {th }}$ century. Moscow, Nauka Publ., 1989, 238 p. (In Russian)

Mironov B. A social history of Russia in the imperial period (1 $18^{\text {th }}-20^{\text {th }}$ centuries): The origin of individuality, the democratic family, civil society, and a law-based state. St. Petersburg, Dmitrii Bulanin Publ., 1999. Vol. 1, 548 p.; Vol. 2, 566 p. (In Russian)

Offord D., Rjéoutski V., Argent G. The French language in Russia: A social, political, cultural, and literary history. Amsterdam, Amsterdam University Press, 2018, 700 p.

Pintner W. Russian economic policy under Nicholas I. Ithaca, Cornell University Press, 1967, 291 p.

Ransel D. A Russian merchant's tale: The life and adventures of Ivan Alekseevich Tolchënov, based on his diary. Bloomington, Indiana University Press, 2009, 353 p.

Schattenberg S. Die korrupte Provinz? Russische Beamte im 19. Jahrhundert. Frankfurt, Campus-Verlag, 2008, 294 S.

Smith A. For the common good and their own well-being: Social estates in imperial Russia. New York, Oxford University Press, 2014, 296 p.

Wortman R. The development of a Russian legal consciousness. Chicago, The University of Chicago Press, $1976,360 \mathrm{p}$.

Zaionchkovskii P. The government apparatus of autocratic Russia in the $19^{\text {th }}$ century. Moscow, Mysl' Publ., 1978, 286 p. (In Russian)

Статья поступила в редакцию 8 августа 2020 г.

Рекомендована в печать 10 декабря 2020 г.

Received: August 8, 2020

Accepted: December 10, 2020 